\title{
SPORT VIOLENCE ON THE FIELD AND OFF THE FIELD
}

\author{
Roma Irawan \\ romairawan@fik.unp.ac.id \\ Universitas Negeri Padang, Indonesia
}

\begin{abstract}
In introducing us to the world of sport violence the key factors in this paper are to define our terms and identify the ways in which sport violence manifests itself as a social problem in contemporary society. Although it has existed in most nations early history, the visibility of sport violence and those who perpetrate it are different today. We see much of this through parents and adult role models who cause a mimi cry of actions. In addition, we see extreme pressure placed on youth to perform well for an athletic scholarship that will never arrive. Indeed, the overemphasis on sport, started at an earlier and earlier age is a tragedy that results all too often in broken hearts, broken dreams and broken families.

The most important impact of violence in sports may be how people use it to reaffirm an ideology of the "natural superiority of men," based in the belief that an ability to engage in violence is part of the essence of being a man. Female athletes in contact sports also engage in aggressive acts, but little is known about how those acts and the willingness to engage in them are linked to the identities of women athletes at different levels of competition. At this time, many women seem to prefer an emphasis on supportive connections between teammates and opponents, as well as on pleasure and participation in sports. Therefore, aggression and violence do not occur as often or in connection with the same dynamics in their sports as in men's sports.
\end{abstract}

\section{Key Word: Sport, Violence On The Field, Violence Off The Field}

\section{A. Introduction}

Statements about violence in sports are often confusing because they are so contradictory. Some people say that violence is an inherent part of many games, whereas others say that violence in any form destroys the dynamics of games. Some people say that violence in sports reflects natural tendencies among males in society, whereas others say that men use violence in sports to promote the idea that physical size and strength is a legitimate basis for 
maintaining power over others. Some say that violence in sports has increased to intolerable levels, whereas others say it is not as frequent or as brutal as it was in the past.

The problem of violence in sport especially sports football which often happened now in European countries including America Latin already is a social issue that must be tackled seriously especially involving the crowd for bad behavior shown by the audience these often have caused the disorder and unrest in society (William, 1989:9). History shows that the act of violence in football has happened since the age of the game of football itself, so that people in general have not felt the strangeness of the problem of violence in football this (Canter, 1989; in Haley and Johnston, 1995:4). Thus most people already consider that the problem of violent football audience is problems that often the case in a game.

About the violence happened in the sport has been registered since the age of roman, but violence occurred at the audience is not yet be likened to conduct violence happened in sports of football this time (Canter, 1989; in Haley and Johnston, 1995:4). Violence in football at the beginning of its development is a fight that happened between village in medieval times, in which opposing groups have to move the ball made of the skin to a place that is guarded by a group of his opponent. The form of the sport of professional football modern was created around 1840. In the beginning it was invented football sport, competition with use of violence is already familiar, so about a period of 1880 , violence involving the audience often happens (Walvin, 1986; in Haley and Johnston, 1995:4). Violence in sport seems to have followed the pattern of the general. Although very difficult to describe the pattern is systematically, but more data shows that the activity of the sport leading to the act of violence is quite serious. Change the rules, the implementation of rules that is not consistent, 
and many of the fact that sport is considered formal breaking the rules, not officially recorded (Smith, 1983:2).

From the above information, about violence problem in sport need to be discussed, violence in sport can happen on in and outside the sports field. In the sports field, violence can be done by a player, coach and the referee involved in the match. Sports violence that occurs outside the field, caused by that happened inside the, have an effect on so that off the field. Violence in this off the field are mostly done the audience who is in the field and even by the audience are watching via television in various places.

\section{B. Literature Review}

\section{Definition of Violence}

This happened during the violence, many people regard as a threat to the environment. Violence related to the condition of fear, the threat, and change the pattern of relationships in society. Things are explained, Neal (1976; in Snyder and Spreitzer, 1989:234) as follows; "violence is regarded as a threat to society or subsystems in society. It involves a condition of fear, threat, and changing the usual pattern of relationships." More specifically, Smith (1983; in Snyder and Spreitzer, 1983:234) explained that "more specifically, violence in sport violates the norms and rules of the contest, threatens lives and property, and usually cannot be anticipated by the person affected."

Of both opinions above, can be understood that a violent action regarded as a threat to society. While the act of violence that is happening in the sport of breaking the rules of a sport itself and cannot be anticipated by the players itself. Next the definition of violence can be explained with reference to the opinion some experts, Smith (1983:2) that "violence, more often than not, refers to the physical side of aggression, hence the term violent aggression. Violence is behaviour intended to injure another person physically." Further 
definition of this violence described by Feshback (1971; in Cox, 1990:266) that "the term violence can be reserved for the more serious manifestations of aggression in sport."

Of some opinion above can be concluded that the term violence is a collection of physical comportment more serious by use of force and devoted to wounding others in this player even out of the field. Following several different definition caused by several factors are intertwined according to Smith (1983:1) between; a) there are differences in perspective (and terminology) among the discipline, that make violence and aggression part of their domain....b) it is probably a mistake to think of violence or aggression in unitary terms, as if all their forms were merely aspects of the same phenomenon, $c$ ) the concepts are loaded with moral, social, and political meanings.

There are several factors that cause the onset of the act of violence, for example the problem of social and cultural transition has caused damage to the rules in the community. With decreasing forms of the tradition of the community, then start looking new sources of identification, including new forms of life group. This is as noted Snyder and Spreitzer (1989:235) that "with the decline of traditional forms of community, new sources of identification have arisen, including new forms of communal living. . . for many people the rise of commercialized sport served as a means of generating new social meanings and identity."

So, for many people, the exercise of the functions as a tool to arouse the emergence of new social identity. Identification by a team sport psychologically serves as compensation for the support of social. Smith (1983:35) explains that "athletics teams that represent high schools, colleges, universities, and cities are supported by dedicated and committed fans. This identification with a sport team may be psychologically functional as a compensation for the loss of community and social supports resulting from urbanization." 
This definition includes conflicts that may occur between players, and it also includes conflicts that arise from one or a combination of the following (Lynn M, (2009:5 - 6):

a. Player: One engaged in a sport experience.

b. Coach: Volunteer or paid leaders of sport teams.

c. Referee/official: Those who regulate game, contest situations.

d. Fan/spectator: Those who observe practices, games or contests either in person or through media.

e. Volunteer: One who serves in a number of roles to help support a sport delivery system and include helpers at events, board members, coaches, parent representatives.

f. Administrator - An individual or group of individuals having direct or indirect authority over the sport environment.

g. Parent/guardian/family - Those related to a player or players.

h. Adult role model - Coaches, teacher, recreation leader, athletes, or anyone who has direct or indirect influence on a player.

i. Business associate - One involved in investing, donating, or supporting the sport with a monetary exchange.

j. Criminal - One who breaks rules to the extent that he/she may be brought up on charges.

k. Terrorist - One who commits crimes for the purpose of giving exposure to a particular ideology, issue of concern, or grudge.

Although sporting events structured and there is the rule is but a game is played in a social context in which the structure tenuous or weak and thus can be interrupted easily. as expressed Lüschen (1970; in Snyder dan Spreitzer, 1989:235) that" .... if sport teams are points of identification with other systems, such as schools, communities, and nations, rivalries coming from other sources may be introduced into a sport contest and thus lead to . . . severe conflict." A similarly, Muzafer Sherif and Carolyn Sherif (1969; in Calhoun, 1987:283) explains that, 
"when members of two groups come into contact with one another in a series of activities that embody goals which each urgently desires, competitive activity toward the goal changes over time, into hostility between the groups and their members."

\section{Violence On The Field}

The most frequently used typology of on the field violence among players is one developed by Mike Smith, a Canadian sociologist (1983; see Young, 2000, 2002a). Smith identified four categories of violence associated with playing sports:

a. Brutal body contact .

b. Borderline violence.

c. Quasi-criminal violence.

d. Criminal violence.

Sociologist Kevin Young $(2000,2002 a)$ has noted that this is a useful general typology but that the lines separating the four types of violence shift over time as norms change in sports and society at large. Violence as deviant overconformity is also related to the insecurity of life in a high-performance sport. Athletes learn that you are only as good as your last game," and they know that their feeling of self-worth, their identities as athletes, and their status as team members are constantly under question. Therefore, many athletes are willing to take extreme measures to prove themselves, even if those measures involve violence.

Violence becomes a means to prove self-worth and reaffirm membership in the sub cultural in group of those who play the game at a high level. This is why athletes who don't play in pain are defined as failures and why those who do play in pain and with injuries are defined as courageous. After all, playing in pain and with Injuries honors the importance of the game and expresses dedication to teammates. 
Next in this year some examples of ethnic violence that which concerns, economy, politics, and pertaining to athletic games, it can be described in war and football the sport of boxing quoted from various sources:

a. The match between Persipura versus Arema, where there is a commotion that caused the commotion players off the field, so this destructive course of the game.

b. Likewise, the game between Semen Padang versus Arema, commotion also occur due to some refereeing decisions in taking decisions. so that at the end of the game there was impairment and violence against referees existing infrastructures and facilities within the stadium.

c. 2016 European Championship qualifying match between the two Balkan countries "Albania versus Serbia on Tuesday (14/10) had to be stopped, after drones that carry the banner of" Albanian Kingdom "flying low over the Partizan Stadium in Belgrade. The match between Albania versus Serbia football match was then turned into a riot when a large number of spectators Serbia ran on to the pitch and tried to attack the players Albania.

d. Here the authors also look at the incidence of violence in the sport of boxing, where a boxer Croatia, Vido Loncar, sanctioned referees for life for beating up on the canvas following its defeat boxer from Algeria, Beniulis.

Of several of them, the evidence shows that support a crowd a group of people against violence was legal and illegal in competitive sports, good affect on increase of tension that can result in a conflict between the boundary with a second game in a orderly audience show high her enthusiasm during the fights between teams of players. Furthermore Calhoun (1987:292), that fights a spectator in caused by a football player. Furthermore, the addition of tension and excitement 
reached its peak, will that is, when the regunya have the same force and the result of the game has an important meaning. This is as noted, Snyder dan Spreitzer (1989:236) that “...the buildup of tension and excitement is greatest when the team are approximately equal in performance and the game outcome is important."

The sport has attracted the audience gathered together and all of which may be affected by the rules, causing aggression and violent confrontation. In sociology, a term collective behavior that is not presently showing the situation. Most football classified as an example in the sport collective behavior, especially the behavior of the crowd of the chaos, tumult, and aggressive behavior of athletes and spectators. Including forms of these behaviors are presently behavior disorder, norms that appears, and the absence of social control mechanisms. During the game, the athletes often feel pain or injury caused the collision with another player. In sports of football, body contact allowed according to the rules of the game. Body contact that occurs in significant (tackle) bone of contention, the collision, and any other action that is considered the shah according to the rules of the game. With physical violence in football is often a result of intentional behavior. By because there is a positive connection between victory and success hence the game hard very prosecuted by supporters of, coach and manager. Every football player had learned so much since early age namely learn how to use various parts of her body to conduct, bone of contention hurdles and offense against others.

Table table below, shows some of the actual types of problems occurring with each category of sport participant that have received attention by the media or been experienced through observation. These incidents have occurred with a frequency that appears to reveal the ultimate acceptance of sport violence as a part of the normal business as usual aspect of sport; however, penalties and concerns have been increasing, and until the social issue of sport violence is 
more comprehensively addressed, incidents such as the ones described may be the cause of activities to be cancelled.

Table 1.1 Violent Episodes Committed by Those in the Sport Environment: (Lynn M, (2009:6 - 7):

\begin{tabular}{|c|c|}
\hline Role & Incidences \\
\hline Player & $\begin{array}{l}\text { Drugs use, domestic battery, weapon possession, } \\
\text { sustaining and giving injuries, fighting, temper } \\
\text { tantrums, illegal gambling, attacking rival player, } \\
\text { obscene gesture, altercations, violating conduct } \\
\text { code, sideline clearing brawls, throwing pitches, } \\
\text { being robbed, disorderly conduct, flagrant fouls, } \\
\text { murder, driving while intoxicated, involved in } \\
\text { shootings, arguing call and spitting seeds, vandalism } \\
\text { and destruction of property, pranks, illegal dog } \\
\text { fighting, lack of respect for referees, hazing, } \\
\text { accidental injury, intentional injury, off-field conduct, } \\
\text { larceny, kicking opposing player, improper on-court } \\
\text { conduct. }\end{array}$ \\
\hline Coach & $\begin{array}{l}\text { Brawls, harassment, sexual harassment, sexual } \\
\text { assault, being stalked, physical assault and battery, } \\
\text { threatened, vandalism, attacking fans, bribing player } \\
\text { to keep autistic child from playing three innings as } \\
\text { required by league, criticism of official, fired over dirty } \\
\text { play, decking opposing player, hazing, coercion of } \\
\text { playing through injury, off-field conduct and hitting } \\
\text { players. }\end{array}$ \\
\hline Referee/official & $\begin{array}{l}\text { Game fixing, unnecessary technical foul, baiting } \\
\text { players, protected by French government actions, } \\
\text { incompetence and inconsistency. }\end{array}$ \\
\hline Fan/spectator & $\begin{array}{l}\text { Illegal acts, pelting players with debris, kidnapping, } \\
\text { attacking school coach, grabbing professional player } \\
\text { and choking, burning couches and mattresses, } \\
\text { streaking, charged in brawling, allowing hazing } \\
\text { rituals, stalking, off-field conduct, bribery, intimidation } \\
\text { of referees, death over jersey, killed by police, killed } \\
\text { by stampede, assault, threatening and detainment of } \\
\text { officials. }\end{array}$ \\
\hline Volunteer & $\begin{array}{l}\text { Theft, hazing, hacking information from French } \\
\text { doping lab, cheerleader trampled by football team. }\end{array}$ \\
\hline Administrator & $\begin{array}{l}\text { Reschedule of practices due to fires, acts of omission } \\
\text { and commission, mismanagement, Maneuvering and } \\
\text { manipulation, permitting continuance of } \\
\text { discrimination, making unacceptable remarks and } \\
\text { perpetuating inequality. }\end{array}$ \\
\hline Parent/guardian/family & $\begin{array}{l}\text { Manslaughter, beatings, permitting hazing, poisoning } \\
\text { players, murder contract, stalking, pressure, child } \\
\text { abuse, threatening, bribing, buying coaches, } \\
\text { promoting inappropriate conduct and permitting } \\
\text { inappropriate conduct. }\end{array}$ \\
\hline General citizen & $\begin{array}{l}\text { Terrorism, hazing, permitting illegal acts, murder, } \\
\text { shooting, hero, suicide of former player, killed by } \\
\text { robbers, bombing at Olympics. }\end{array}$ \\
\hline Business associate & Trainer released from prison, shoving, rigging and \\
\hline
\end{tabular}




\begin{tabular}{|l|l|}
\hline Criminal/terrorist & making improper payments to player. \\
\hline & $\begin{array}{l}\text { Stray bullets, using field for terrorism, threatening } \\
\text { large gatherings of sport enthusiasts. }\end{array}$ \\
\hline
\end{tabular}

Based on the table, a mild form of violence and the weight, they still clung to this as in sport, and often causing bedlam strife and is usually regarded as a result of a that football sport regarded as miniature of violence.

\section{Violence Off The Field}

When athletes in contact sports are arrested for violent crimes, many people assume that their violence off the field is related to the violent strategies they have learned and are rewarded for on the field. Research suggests that male athletes who have many years of experience in power and performance sports are, more likely than recreational players or nonplayers to approve of off the field violence and to use violence when they play other sports (Bloom and Smith, 1996). These results are helpful but they still do not say whether violence in hockey is a cause or an effect violence that occurs in other spheres of the players' lives.

He also concludes that comparing assault rates of athletes with those of nonathletes distracts us from the following important points:

a. Violence against women does occur.

b. It is a serious problem.

c. Male athletes are among the perpetrators of this violence.

d. We must understand the problem within the context of sports if we wish to deter assaults perpetrated by athletes.

Building on the frame work developed by crossed, and combining it with other research on patterns of violence in all male groups, I hypothesize that a combination of the following factors accounts for male athletes' violence against women: 
a. Support from teammates and fellow athletes for the use of force as a strategy for "doing" masculinity in their lives and being a man in their relationships with women

b. Perceived cultural support for an emphasis on physical domination as a source of status in the community and as a basis for identity as a man and an athlete

c. Deviant overconformity to the norms of the sport ethic, to the point that it creates strong social bonds among teammates, strong feelings that others cannot understand them or their experiences in sports, and a strong sense of hubris (i.e., pride-driven arrogance)

d. Collective hubris among team members supporting the notions that those outside the fraternity of elite athletes do not deserve respect, that elite athletes can expect outsiders to defer to their wishes and demands, and that elite athletes live outside the norms of the general community

e. Support within their social world for the belief that women (apart from their own mothers and sisters) are "groupies" seeking status through relationships with elite athletes and that athletes need not take responsibility for the consequences of relationships with women

f. Institutional (team, athletic department, university, community) support for elite athletes, regardless of their actions

g. Intitutional failure to hold elite athletes accountable when they violate community norms and rules.

With this in mind, the following list includes places where sport violence has occurred, (Lynn M, (2009:11):

a. Site of actual contest, practice and preparation.

b. Sites adjacent to actual contest, practice and preparation.

c. Sites associated with sport organization such as homes, social events and travel venues. 
d. Sites not directly associated with sport venues such as home, casino, theatres, dormitories etc.

e. Hazing sites associated with initiation activities such as locker rooms, remote areas, backyards and parks.

f. Organizational offices where meetings and pre-planning are held.

g. Business establishments that are gathering places for large groups of fans or viewing audiences.

h. Universities.

i. Anywhere.

This part of an explanation, can be taken the conclusion that the act of violence occurring in sports, whether it was conducted by players or spectators particularly in the game and damaging the rules of soccer match in the community norms, so it is likely also will be injurious to life in society. The act of violence usually done the players and happened in sports group containing elements body contact, and often climbing into the stands where audiences are, thus causing the occurrence of violence between the audience, even the action came to the streets and damaging public facilities.

\section{SUMMARY}

In introducing us to the world of sport violence the key factors in this paper are to define our terms and identify the ways in which sport violence manifests itself as a social problem in contemporary society. Although it has existed in most nation's early history, the visibility of sport violence and those who perpetrate it are different today. We see much of this through parents and adult role models who cause a mimi cry of actions. In addition, we see extreme pressure placed on youth to perform well for an athletic scholarship that will never arrive. Indeed, the overemphasis on sport, started at an earlier and earlier age is a 
tragedy that results all too often in broken hearts, broken dreams and broken families.

The most important impact of violence in sports may be how people use it to reaffirm an ideology of the "natural superiority of men," based in the belief that an ability to engage in violence is part of the essence of being a man. Female athletes in contact sports also engage in aggressive acts, but little is known about how those acts and the willingness to engage in them are linked to the identities of women athletes at different levels of competition. At this time, many women seem to prefer an emphasis on supportive connections between teammates and opponents, as well as on pleasure and participation in sports. Therefore, aggression and violence do not occur as often or in connection with the same dynamics in their sports as in men's sports.

\section{References}

Calhoun, DW (1987). Sport, Culture, and Personality. Second Edition. Illinois. Human Kinetics Publishers, Inc. Champaign

Coakley, J.J., (2003). Sports in Society: Issues and Controversies, 8th edn. McGraw Hill Higher Education, Hightstown, NJ, p. 676.

Cox, H R. (1985). Sport psychology, Concepts and Application. Second Edition.

Haley, AJ. Johnston, BS (1995 ). Menaces to Management ; A Developmental View of British Soccer Hooligans, 1961-1986.

Lynn M. Jamieson, (2009). Sport and Violence: A Critical Examination of Sport. Burlington, MA 01803, USA.

Smith, Michael D. (1983). Violence and Sport. . Canada. Butterworth \& Co.

Snyder, E.E. Spreitzer (1989). Social Aspects of Sport. Third Edition. Englewood Cliffs, New Jersey. Prentice Hall 